\title{
Pierre Bourdieu and his concept of Symbolic Violence: what's happening into Colombian Classrooms?
}

\author{
Jesús Antonio Quiñones ${ }^{1}$
}

Recibido: $21-04-2017$

Aceptado: 25-05-2017

\begin{abstract}
This discussion paper arises from the academic proposal made for elective seminar of the Doctorate in Education from Universidad Santo Tomás in Bogotá Colombia 'la violencia simbólica en la obra de Pierre Bourdieu y el acto pedagógico'. In a very particular scenario being presented in the Colombian nation in recent months in which the political, economic and cultural academic country seeks ways out of decades of war between the government and armed opposition groups, it is necessary that this topic enters into the classroom and reflect about these very pointed and particular tensions that every day are fought at schools, colleges or universities. In this sense, one of them has to do with power relationships between teachers and students, the study of its genesis, its development and evolution are essential for understanding today's school as the setting in which they are educating the new generation of Colombians who, apparently, will be the first to live in a country at peace.
\end{abstract}

It is assumed therefore that the author's ideas on Bourdieu's theory stem from the author's experience of working in Colombia as a teacher in several schools and universities. After years of pedagogical experiences, this would make an interesting insight, through the lens of Bourdieu, into the dominant educational pedagogical approach in a country which is perceived to be unstable by other nations. A position paper on how students may be discriminated against or oppressed because of the power struggles or tensions within the classroom and what Bourdieu might call cultural arbitraries, would make interesting reading. For this 
analysis, it is assumed that the theory of Pierre Bourdieu can be helpful to understand this phenomenon, since it allows to address the issue from the theoretical but also leaves the possibility of understanding the phenomenon from teaching practice and the school.

Keywords: classroom, education, symbolic violence, pedagogical act.

\section{Pierre Bourdieu y su concepto de violencia simbólica: ¿Qué pasa en las aulas colombianas?}

\section{RESUMEN}

Este trabajo surge de la propuesta académica hecha para el seminario electivo del Doctorado en Educación de la Universidad Santo Tomás en Bogotá Colombia 'La violencia simbólica en la obra de Pierre Bourdieu y el acto pedagógico'. En un escenario muy particular que se presenta en la nación colombiana en los últimos meses en que el escenario académico político, económico y cultural busca salir de décadas de guerra entre el gobierno y los grupos armados de oposición, es necesario que este tema entre en el aula y reflexionar sobre estas tensiones muy acentuadas y particulares que cada día se luchan en escuelas, colegios o universidades. En este sentido, uno de ellos tiene que ver con las relaciones de poder entre maestros y estudiantes, el estudio de su génesis, su desarrollo y evolución; son esenciales para entender la escuela de hoy como el escenario en el que están educando a la nueva generación de colombianos que aparentemente, será el primero en vivir en un país en paz.

Por lo tanto, se supone que las ideas del autor sobre la teoría de Bourdieu provienen de la experiencia de trabajar en Colombia como profesor en varias escuelas y universidades. Después de años de experiencias pedagógicas, esto haría una interesante visión, a través de la visión de Bourdieu, en el enfoque educativo pedagógico dominante en un país que es percibido como inestable por otras naciones. Este documento analiza cómo los estudiantes pueden ser discriminados $u$ oprimidos debido a las luchas de poder o las tensiones dentro del aula y lo que Bourdieu podría llamar los arbitrarios culturales, haría lectura interesante. Para 
este análisis, se supone que la teoría de Pierre Bourdieu puede ser útil para entender este fenómeno, ya que permite abordar el tema desde lo teórico pero también deja la posibilidad de entender el fenómeno desde la práctica docente y la escuela.

Palabras clave: aula, educación, violencia simbólica, acto pedagógico.

\section{Introduction}

In Colombia, the teachers from preschool to secondary usually are doing different things into the classroom. It means that they go into this place and they 'try' to develop a topic according with their knowledge and expertise. Once the class is finished, the teacher leaves out the classroom and the students wait for the next one, or they go to the playground or just they continue their day outside the school. To maintain the students into the classroom and having the purpose of developing the topic, the teachers usually establish some conditions and rules during the class that ought to be assumed by the students. This article proposes a review of this phenomena (the correlation of forces into the classroom) focusing on the perspective of the concept of symbolic violence by Pierre Bourdieu and contextualized into Colombian schools. It is a way to reflect on the teacher's practice and how to balance the forces into the educational process. According to this author, teacher's actions and decisions into the classroom are called the pedagogic action (PA) that are, objectively, 'symbolic violence insofar as it is the imposition of a cultural arbitrary by an arbitrary power' (Bourdieu, 1990, p. 5). It is a kind of a balance of forces between the teachers and students (not to mention the principal of the school, the parents of the students and even the ministry of education of the country). All of these educational agents are trying to show who must lead the educational process.

\section{Teacher power in Colombia nowadays}

The main topic of this article is to reflect about the teacher power. To contextualize this and because the author of the article has been just 
working as a teacher in Colombia, it focus on what is happening in this country. But, for everyone who is living or have travelled overseas, the teacher power and the student's attitude is similar into the classrooms even in other countries. That is, lack of authority, a struggle between teachers and students to show who is the boss and so on. In summary, this is not a Colombian phenomenon, this is a real situation in all schools and universities around the globe.

The teacher in the classroom holds legitimate power. In fact, teaching practice gives power as one having authority, a socially recognized person, available to evaluate and even punish learning and student behavior to be better than others. Obviously, all within the framework established by law, but the ambiguity of it in Colombia certain respects and own privacy classroom allows much framework decision. In this country, a teacher has the power to determine what is correct and appropriate for students and what not. Also, to establish the limits of what is true and important and false and irrelevant, even to control the language, dress and behavior of students. All this without resorting to arguments to sustain such criteria. In addition, a teacher must be able to understand the student's feelings so deeply, also their emotions and even their home problems. At least, the Ministry of Education of Colombia says this (2005, p. 3).

\begin{abstract}
Besides knowing their discipline and means to achieve understanding and learning, the teacher needs to know how to communicate, hear active and respectful manner different postures, include and value differences, so as arouse curiosity for knowledge, according to the developmental stages of each student. The teacher identifies their emotions and those of students and channeled constructively. In their daily practice, the teacher faces their students and their expectations, as diverse as the number of apprentices in the classroom, and it agrees with the particularities each.
\end{abstract}

Also, teachers must know that each student is diverse and understand ways and sources of motivation to learn. It is important to handle these differences to ensure learning for all. This brings us to the classroom culture. A group class is a micro culture with their symbols, their jargon, their common history, values, etc. Any teacher who imparts a class into several groups perceive that they are very different cultures. Each of these groups recognizes its members to the extent that share its symbols (external elements such as type of clothing, piercings, tattoos, hairstyles, 
hangouts -definition of their spaces- ...) and behavior (language and vocabulary, hobbies, action-consumption of certain drugs, certain acts of vandalisms-, etc.). These cultures can be established equal power struggles, ie, explicit or implied, to get to impose their vision and their values on the rest of the class clashes. For example, those cultures assume a value of opposition or school refusal try to impose on groups bearing a positive attitude towards it; or the culture of boys who tend to be imposed on women. These struggles generate tensions in the classroom that can be a source of disciplinary problems.

From these characteristics, teachers design their classes and adapt materials according to the needs and pedagogical challenges they face. To do this, Colombian teachers are forced to update their knowledge and constantly develop skills and attitudes that enable them to respond effectively to challenges by developing what students should know and do know. 'Thus, training skills (Basic, civic and labor), to their students, is both an incentive for personal development' (Ministerio de Educación Nacional, 2005, p. 4).

Science teachers based on their aesthetic pleasure of their explanations, how hypotheses are confronted and ideas for strengthening or refutation encourage development of scientific thought in their students. They also promote democratic environments that allows teachers the dialogue of knowledge. A dialogue in which each participates in building discussion by recognizing good arguments using self-criticism. For students, the teacher is a life example, an image of authority and respect. That is, it is a landmark in the consolidation of their own identity. Teachers "Must be willing to understand their strategies, needs, values and defects, reflect on their own teaching and effects on students, develop a philosophy against education, appreciate the responsibility to serve positively model for learners, accept changes, ambiguities and errors" (Ministerio de Educación Nacional, 2005, p. 6).

Also, teachers are inspiring for the development of social values such as tolerance, honesty, justice and equity, and to highlight and protect engines the social value of cultural differences. In addition, when the student warns solidarity and cooperation among teachers your -including institution with those of other institutions, are encouraged to develop these practices to achieve its academic objectives. This hierarchically superior position that can lead teachers to legitimize certain beliefs, values and practices by virtue of their position of authority is what makes 
teaching a political phenomenon, which implies a moral responsibility on the part of teachers to accept a compromise with the welfare of their students in the exercise of that power.

Also, 'the power of the teacher derives a portion of its adult status, their greater mastery of imparting knowledge and his power, by societies to assess and punish both school performance and student behavior' (Ministerio de Educación Nacional, 2005, p. 7). However, today we speak of a crisis of the authority of teachers. If we analyze the pillars of his power, we will see that currently there is no guarantee of anything. On the one hand, because adulthood is not valued. Today's society values youth, adolescence and we all want to pretend to be younger than we are. Experience and wisdom are not issues that are considered. Knowledge is not a postmodern society value. New technologies have made access to information easier for all; He is no longer the school teacher and the source of wisdom par excellence. In addition, the value of the exoteric, the occult, witchcraft and divination art is in vogue, questioning the scientific knowledge as a source of truth. Finally, evaluation is something that has been weakened with the extension of compulsory education; automatic promotion, restricting the possibilities of repetition, subjective criteria for promotion from one course to another have led to the evaluation Enforcer and has lost its power to impose sanctions. As a result of this, the teacher's authority in Colombia has been weakened.

\section{Bourdieu's theory: useful to understand daily behavior phenomena in Colombian classrooms}

It's school time. Early in the morning, students and teachers have a daily 'date' inside the educational building. For some of them, it's time to 'fight another round.' Teachers must fight to maintain the student's attention, and the students must fight against the 'oppressive system' that assigns them school duties and so on. To maintain the students into the classroom and having the purpose of developing the topic, the teacher usually establishes some conditions and rules into the class (Quiñones, 2016, p. 10).

The legitimate role of students is that of subordination. They are expected to lead in learning, language, behavior, even aesthetics, without any questions. They are positively or negatively praised and are expected 
to willingly accept these valuations. The student's role is submission to the authority of power, occupying the lower hierarchical position in power relations established in the classroom. But it is easily understandable that no one accepts this submission without more, especially in some circumstances, as in the case of arbitrary, unfair and partial teachers; also it is clear that this acceptance easier in contexts where students can participate in making decisions implicit in power and not feel as capricious imposition.

Students also want to take heights of power in the classroom and neutralize, if not counter, the authority of the teacher. These phenomena of resistance may adopt a passive way (going from school, no homework, not studying for exams, do not bring the notebook to class) or active (disruptive behavior, insults, disobeying orders, destroying the material or school furniture). Although these resistors can be exercised individually by a student, the power of students is a group power. That is, a student alone can be neutralized easily. The problem begins when a group of students assume these behaviors together supporting each other's resistance.

When we research at the library or even the internet about pedagogical phenomena into Colombian classrooms, we must take a look of Bourdieu's theory about the pedagogical act, symbolic violence and also teacher power. According to this, we realize that Bourdieu was able to investigate cultural transmission as a strategic process of family based intergenerational reproduction (1974, p. 7). Also, the author clarifies that the educational system and the classroom has become the most important agency for the reproduction of ideas, manners and even to establish how to be a citizen of today's society. This insight enabled Bourdieu (1974, p. 8) to challenge the optimistic liberal perception of the school as an instrument of social reform and equality, and it has taken him to more refined analyses of the creation and recreation of the difference.

Bourdieu's theories have influenced both sociologists, educators and teachers, and has generated a lot of literature both theoretical and empirical. Some theorists say that his theories have lost value in recent years, while others say that his thinking is still useful today. Therefore, this paper seeks to examine the theory and use by researchers in the fields of education. The work of Pierre Bourdieu should go into the classroom and should be used to think about ways to solve problems that arise in the school. Theories such as habitus, cultural capital and power relations are mediated by the educational system. 
According to Bourdieu, 'educational systems of industrialized societies operate in such a way that legitimize class inequalities' (1974, p. 47). From the perspective of teachers, success in the education system is facilitated by the possession of cultural capital. The problem is that students do not receive the same quality and quantity of knowledge needed to achieve clarity of knowledge. This can lead to school failure. 'If explicitly giving everyone implicitly requires all are deleted; the system requires education of all alike with what does not. This mainly consists of linguistic and cultural competence and that the relationship that can only be produced by family education when the dominant culture is transmitted' (Bourdieu, 1977a, p. 494).

In addition to cultural capital, Bourdieu introduces the complementary concept of cultural arbitrariness, but he doesn't define the concept. However, he states: 'In any given social formation legitimate pedagogical action, i.e., the pedagogical action endowed with the dominant legitimacy, is nothing more than the arbitrary imposition of culturally dominant arbitrary, while evil is recognized in its objective truth as the dominant pedagogical action and the imposition of the dominant culture' (Bourdieu and Passeron, 1990, p. 22).

As Bourdieu uses the term 'cultural arbitrary' without defining it, it is unclear exactly what he means when he refers to the arbitrariness, what the limits of the concept are or what is considered arbitrary or not. Whether it is at the discretion of each person who etymologically analyzes the concept, or to what extent the required skills are acquired in a particular cultural context.

In some cases, the educational levels, from kindergarten to postgraduate education are clearly described by Bourdieu in any arbitrary direction. 'The system of provisions to school, understood as a propensity to consent to the investment in time, effort and money it takes to preserve and enhance the cultural capital'. (Bourdieu, 1977a, p. 495). This is where the school is the raison d'etre of the whole society. It is a natural academic space that allows the transmission of cultural capital from a person. In this case, teachers, with the support of their life experience and academic qualifications, which legitimizes them to lead and guide the educational community and teach a group of students who require training, education and new knowledge for life. 


\section{The cultural autonomy of the School: too much arbitrary?}

Bourdieu (1971, pp. 192-193) writes, 'it may be assumed that every individual owes to the type of schooling he has received a set of basic, deeply internalized master patterns'. This means that school is a place that legitimizes their own power, which remain from the academic relations between teachers and students. The school is a space that form and guide consciences even the identity of nations. It is clear that the role of the school is recognized and accepted as currently active and necessary, and not merely passive in its 'legitimacy' of the established order that exists in society.

The school is the most responsive institution to Bourdieu's theory in the sense of responding to a clearly arbitrary cultural code, prepared and organized by the academic community where students have little to say about it (Bourdieu, 1974, p. 41). So, the arbitrary is accepted by the academic community, legalized into the school routines and in general all of the educational system as a place where even no other space is the most suitable for acquiring knowledge and being part of a society ruled by cultural society codes. Related to this issue, one cannot ignore the reality of the classroom as the space where power is shown by teachers and even students. Each of these actors wants to show some power, which is a basic human need. The teacher also has this desire for power and as previously mentioned, is protected by their experience and academic qualifications.

\section{Symbolic violence into the classroom: the teacher's masterpiece?}

Bourdieu made an incisive analysis of the exchange of gifts as a mechanism through which power is exercised and not in terms of a formal structure of reciprocity. In a society where there are relatively few institutions that can provide stable and objective relations of domination form, individuals must resort to the more personalized to exercise power over others, as in a gift or debt. By this way, symbolic violence "transform the relations of domination and submission in relationships, power in charisma" (Bourdieu, 1977, p. 406). The recognition of the debt becomes 
gratitude, lasting feeling about the author of the generous act, which can reach affection or love, as is particularly evident in relations between generations. This symbolic alchemy produces the benefit of those who carried out acts capital of symbolic recognition that report, likely benefits of becoming economic benefits. This is what Bourdieu calls symbolic capital. "Symbolic capital is any property, physical strength, wealth, warrior value, perceived by some gifted social agents of the categories of perception and valuation allow perceive, know and recognize, becomes symbolically efficient, as a true magical force" (Bourdieu, 1999c: 172-173).

In the most differentiated societies, with an appropriate institutional development, it diminishes the importance and effectiveness of the strategies of personal domination through symbolic violence, but it does not disappear. On the contrary it becomes much more diffuse as something inherent to the dynamics of different fields that shape social universes. In late capitalism we can see some defense mechanisms against protest movements aroused by the most brutal forms of economic exploitation that suggest a return to modes of accumulation founded on the conversion of economic capital into symbolic capital.

Bourdieu has deployed all his energy to research how it emerges, how it is exercised and how the symbolic power plays in such diverse fields as education, linguistic, religious, scientific, cultural, family or political. 'There is a symbolic power as well as an economic power; this is the reason that claims to focus their research on the role played processes, producers and cultural institutions in the production and reproduction of inequality in contemporary societies' (Bourdieu, 1989b: 555). Bourdieu's mode has the symbolic power of thinking as it relates to their way of conceptualizing the different symbolic systems, art, religion, science, or the same language. In a synthesis of several different theoretical traditions presented in the most concise way in its article 'Sur le pouvoir symbolique' (1977b), and in more detail in 'Genesis and structure of the religious field' (1971a) and reproduction (Bourdieu and Passeron, 2002), Bourdieu argues that symbolic systems are grounded in a cultural arbitrary, perform three interrelated but different functions simultaneously: knowledge, communication and social differentiation. Symbolic systems are communication tools and domination, make possible the logical and moral consensus, while contributing to the reproduction of social order (Bourdieu, 1971a, 1977b; Swartz, 1997: 8283). 


\section{Conclusions}

Due to the fact that the teacher is in the role of guiding the class required to maintain power for the development of the class in every way, the teacher must be very skilled to maintain that power and influence student behavior. This could be called the power of the teacher. This is neither more nor less than the right to ask students to observe appropriate standards of behavior and allow to be guided in each class academically and along the course. Therefore, the power of the teacher in the classroom is essential, and if it is lost or does not exist, the chances of success as a teacher are very limited.

Professors unaware of what goes on in the classroom, only observe the external symptoms, so they cannot act on the causes. Sometimes the problems between student groups are known only to them, so that teachers cannot do anything. However, many problematic behaviors or performance problems in some students may be due to these stresses. Not spend more time mentoring work classroom culture and clashes between groups. Also, consider that some students aspire to be accepted in a given herd and consequently exhibit those behaviors that will help them to be part of the group. Certain disruptive behaviors are understood from these aspirations. Without the 'symbolic violence', the teacher must lead the class.

According to Quiñones (2009, p. 44),

Debemos recordar que la educación es un componente importante en la humanización y culturización de los individuos. En la humanización, por cuanto a través de la educación se busca mejorar a la persona como individuo, como ser humano «porque impregna cuanto puede llevar a la vida a su plenitud y su plena realización social y aporta provecho y satisfacción personal y grupal» (Belmonte 2004: 5): es a través de ella que se pueden transmitir los valores que la sociedad necesita para desarrollarse, aquellos que determinan nuestro valor como personas. De nada serviría ser un profundo conocedor de una ciencia si no se han adquirido los valores que son necesarios para vivir en sociedad; el respeto a la vida, la tolerancia, la convivencia, la honestidad y la justicia entre otros, son valores transmitidos en el diario vivir de la escuela, necesarios para vivir en comunidad. 


\begin{abstract}
Also, as Arias wrote (2009, p. 66),
"In the current society to think about teaching as a profession, implies to identify clearly the teacher's role in the construction of the society. From this perspective and the nowadays requirements, teacher is not a simple doer of programming processes, more than this, and based on elements given by the social research, he/ she becomes an agent of transformation projects. Thus, it is necessary to identify the challenges and the difficulties that a teacher faces and tries to exceed everyday by being permanent qualified and engaging to perform his/ her job better and better. This involves the teacher as a social researcher and projects agent directed towards the cultural transformation and social problems solution".
\end{abstract}

\title{
Referencias bibliográficas
}

Arias, N. (2009). El Maestro Como Gestor de Proyectos e Investigador Social. En: RIIEP, Revista Interamericana de Investigación, Educación y Pedagogía. Vol. 2, no. 1. Disponible en: http://revistas.usta.edu.co/index.php/riiep/article/view/1290. DOI: http://dx.doi.org/10.15332/s1657-107X.2009.0001.04

Bourdieu, P. (1974). The school as a conservative force: scholastic and cultural inequalities, in: en M.F. D. Young (ed.), Intelectual field and creative project, London: Collier-Macmillan.

Bourdieu, P. (1977). Sur le pouvoir simbolique. Annales, 3 (may-june), 405-411.

Bourdieu, P. (1989). Reproduction Interdite. La dimension symbolique de la domination économique., Études Rurales, 113-114 (janv-juin), 15-36.

Bourdieu, P. (1991). Language and symbolic power. London: Polity Press.

Bourdieu, P. (1999). Razones prácticas. Sobre la teoría de la acción, 2ª edic, Barcelona: Anagrama.

Bourdieu, P., Passeron, J.C. (1990). Reproduction in education, society and culture. London: Sage.

California State University, Los Angeles. The five forms of teacher power. (S.D.) Available at: http://web.calstatela.edu/faculty/jshindl/cm/Teacherpower.htm 
Eggleston, J. (Ed.). (2011). Contemporary Research in the Sociology of Education. London: Routledge.

Ministerio de Educación Nacional. (2005). Revolución educativa al tablero. № 34 Abril-mayo de 2005, p. 3-4. Available at: http://www.mineducacion.gov.co/1621/ propertyvalue-31232.html

Muñoz, P. Et al. (2014). Formación ciudadana: discursos de educadores y estudiantes sobre las actitudes y el pensamiento crítico orientados al ejercicio de la ciudadanía. En: RIIEP, Revista Interamericana de Investigación, Educación y Pedagogía. Vol. 7, no. 1. Disponible en http://revistas.usta.edu.co/index.php/riiep/article/view/1331. Doi: http://dx.doi.org/10.15332/s1657-107X.2014.0001.06

Nash, R. (1990). Bourdieu on Education and Social and Cultural Reproduction. British Journal of Sociology of Education, 11(4), 431-447.

Quiñones, J. (2016). Pedagogic action on Pierre Bourdieu: a brief review of the concept. Available at: http://pub.lucidpress.com/FACULTY_Vol3_Issue2/\#6L fVla.9NvY

Quiñones, J. (2012). La globalización de la educación: lo humano, lo social y sus posibilidades de futuro. Educación, 18(35), 41-52. Recuperado de http://revistas.pucp. edu.pe/index.php/educacion/article/view/1765

Schrodt, P., Whitt, P.L., and Truman, P.D. (2007). Reconsidering the measurement of teacher power use in the college classroom. Communication Education, 56 (3), 308332.

Sullivan, A. (2002). Bourdieu and education: how useful is Bourdieu's theory for researchers? The Netherlands 'Journal of Social Sciences; 38(110. 2), 144-166. 